James, N. (in press) 'The Use of Email Interviewing as a Qualitative Method of Inquiry in Educational Research’ British Educational Research Journal

Address for Correspondence: Dr Nalita James, Centre for Labour Market Studies, University of Leicester, 7-9 Salisbury Road, Leicester, LE1 7QR, UK. Tel: +44 (0) 116252 5957, Fax: +44(0) 116252 5953, email: nalita.james@leicester.ac.uk 


\title{
The Use of Email Interviewing as a Qualitative Method of Inquiry in Educational Research
}

\begin{abstract}
This paper argues for the potential that email interviewing has as a qualitative method in educational research. The paper draws on research that uses email as a way of generating online narratives in order to understand how academics construct their identities. In doing so, the paper considers the challenges that email interviewing poses for researchers who might wish to use the method as a way of studying and understanding academics' lives, particularly the nature of 'presentation' and 'performance' that takes place with/in email narratives. Nonetheless, despite these challenges, the paper concludes by recognising the possibilities the method has for increasing reflexivity by providing both the time and space for academics to construct, reflect upon and learn from their stories of experience.
\end{abstract}




\section{The Use of Email Interviewing as a Qualitative Method of Inquiry in Educational Research}

\section{Introduction}

The growth of information and communication technologies (ICT) in qualitative research have opened up new opportunities for researchers to examine how traditional research methods can be adopted for effective online research (Jones 1999, Johns et al 2004). More specifically, Mann and Stewart (2000) have shown how Internet technology can be used to adapt qualitative methods of data collection in order to obtain rich, descriptive data online and understand human experience. The studies described in such texts highlight how online research is multidisciplinary and multiparadigmatic in approach (Denzin 2004). Such studies also demonstrate the way in which qualitative researchers have developed their technological skills to work online with a variety of methods and practices such as focus groups, chat rooms and conferences to explore online experiences and behaviour in the virtual world (O'Connor and Madge 2001, Eichorn 2001, Williams and Robson 2004).

The use of ICT as an integral element of teachers' professional lives has also led to approaches of researching teaching that involve exploring their experiences online through critical dialogue to identify and interpret professional knowledge and identity as a teacher (Russell and Bullock 1999, Henson et al 2000). In the academic community, email and the Internet has also had a 
profound effect on the way in which academics teach and engage with students, as well as with the wider academic population more generally (Foster 1994, Reed 2004). Yet, given its importance as a medium of communication in higher education, discussion of such technology as an academic research tool to date is scarce. An exploration of the literature indicates that only a few researchers have adopted it to explore for example, the online experiences of undergraduates in their academic performance, e-learning, and the ethics of teaching management accounting (Leman and Mann 1999, Salmon 2000, Bampton and Cowton 2004). It would seem that email has yet to be explored as a method that can bring exciting possibilities and originality to ethnographic research design when it is used to explore how academics construct and sustain their identities.

This paper, therefore, seeks to bridge the research gap by firstly exploring the way in which identity is built in and through the continuity of narrative accounts that individuals tell about themselves, and the use of this approach in educational research, particularly in relation to the study of academic identities. The paper then draws on a research study that used email as a way of generating academics' narratives online in order to understand how they construct their academic identities. In doing this, it explores the challenges that email interviewing poses for researchers who might wish to use the method as a way of studying academics' lives, particularly the nature and management of 'presentation' online and the 'performance' that takes place with/in email narratives. Despite these dilemmas, the paper concludes by recognising the methodological contribution that email interviewing can make to studying academics' lives and the way in which it can increase reflexivity by providing both the time and space for academics to construct, reflect upon and learn from their stories of experience. 


\section{The Construction of Identity through Narrative}

Narrative is a familiar term in the field of education and social sciences, offering an exploratory way forward in which individuals make sense of their lives, the lives of others and the contexts in which they live through telling and hearing/reading stories (Sikes 2002). As Clough (2002) remarks, narratives can open up a deeper view of life that is derived from real events, feelings and conversations as well as exposing those experiences, which might otherwise not be heard or read. It is through narrative that individuals' identities and self-concepts are drawn together and made sense of in the course of biography, and that past, present and future events are linked together by individuals as an ongoing process organized as an unfolding story (Polkinghorne 1988, Connelly and Clandinin 1990). In this sense, identity formation becomes '...the product of, and realized in, narrative accounts of individuals' past present and future...' (Williams 2000, p.81).

In educational research, narrative studies provide the frameworks through which teachers' voices can be heard in educational dialogue and within which new meanings can be brought to the activity of being a teacher. Teachers' narratives reflect their experiences, as they redefine their personal and professional selves (Cortazzi 1993). This raises the question as to how far this mode of thinking about narratives is reflected in the depiction of academic life and the construction of academic identities. Henkel (2000) has argued that academic narratives have been built up predominantly within idealist or essentialist conceptions of academia in which the expression of 
ideals and values have been significant in the way academics conduct and bring about growth and change in their professional lives (Grant and Knowles 2000, Askling 2001). However, the fragmentation of the academic workplace and the increased differentials between individuals in terms of status and autonomy has also had a profound effect on the role of academics and their sense of identity (Nixon 1996, Nixon et al 2001). This has led to major changes and false distinctions about what it means to be an academic, disturbing the values and structures within which academic identities have been sustained (Henkel 2000). This suggests that academic identities cannot be merely 'read-off' from a given context (Halford and Leonard 2001), and will involve individual choices that are not only shaped by relations with the academic community, but also involve individuals engaged in critical dialogue about their teaching and learning.

Using narrative then is much more than '...look for and hear story... Narrative inquiry in the field is a form of living, a way of life...' (Clandinin and Connelly 2000, p.78). Following these principles, a number of different narrative methods have been developed that focus on the particularities of experience. These include autobiographical and biographical writing, journal records and field notes of the shared experience through participant observation, as well as interviewing. Czarnaskia (2004) has argued that narrative interviews can actually become more like a reciprocal conversation between researcher and participant and can provide '...a rich source of knowledge about social practice insofar as they produce narratives' (p.50). Such conversations can also become part of an ongoing narrative record in which participants make sense of their experience as lived and told stories (Connelly and Clandinin 1988). Educational researchers who have used a narrative approach to interview teachers found that their interviews included a level of performance from the teachers that involved a genuine representation of their 
lives (Weber 1993, Connelly and Clandinin 1999). As Clandinin and Connelly (2000) comment: '.. the people, the schools, the educational landscapes we study undergo day-by-day experiences that are contextualized within a longer-term historical narrative' (p.19).

Such studies illustrate how interviews can produce narratives in which, prompted by the researcher, the focus is on recalling and reliving experience and involves individuals constructing and reconstructing their personal and professional narratives through self-images (Beattie 1995). Hence, the interviews become a site for narrative production and provide a way of understanding and representing experience. This places emphasis on the voice in educational research and the need for individuals to talk about their experiences in their own words. As Cortazzi (1993) suggests: 'The narrative account must therefore carry the teacher's voice if researchers and other observers are to know what a teacher knows or feels' (p.11).

\section{Using Email Interviewing to Construct Online Narratives}

As a researcher I was particularly interested in undertaking ethnographic research to explore and understand how a group of senior academics constructed their academic identities across the communities of practice which were of primary importance to them (James 2003). There were 20 academics who took part in my study, 12 of whom were female, and the remainder were male. They all taught psychology in post-1992 higher education institutions across the UK and had been based in their institutions for over a period of five years. They were also active members of their professional body. 
Methodologically, this approach emphasised the need for a research method which would become a site for narrative production and adequately capture and reflect academics' narrative accounts of how they saw themselves, with a view to revealing some of the fundamental structures of their experience (James 2003). I wanted to explore whether email interviewing could be recognised as a legitimate methodology in the study of academic lives, how it could be used to generate narratives of their experience in their voice, as well as meet their needs as research participants and become a central place to document how they, '...live out their lives, find and maintain connections and seek to represent themselves to others' (Hardey 2004, p.12).

The advantages of using online research methods, such as accessing hard to reach groups due to practical constraints (money, time, travel), disability and language or communication differences have been well documented (Jones 1999, Mann and Stewart 2000). I was also interested in the way in which the compression of space and time online meant that geographically dispersed groups, for example families, communities or institutions were no longer isolated from the context and traditions in which they belonged, providing a 'bounded space' within which it was possible to explore how they lived and worked (Henkel 2000). In the academic community, email is used on a daily basis in their working lives for teaching and research and although it is not always perceived as a good thing (Reed 2004), this did not make my participants resistant to taking part in the study. Additionally, using email enabled me to overcome a number of practical constraints that I faced if I conducted face-to-face interviews (for example costs associated with travel and data transcription), so I was able to interview academics located in universities across the UK, rather than being constrained to a local population. 
This placed email interviewing within a 'virtual' ethnographic approach in which I attempted to '...gain a better understanding of the meaning that community members generate through conversation' (LeBesco 2004, p.63). This involved, ‘...careful dialectical reflection on authentic and evocative written accounts of an experience [which] can reveal some of the fundamental structures of that experience' (Weber 1993, p.75). This added to the methodologically interesting possibilities for the creation of an alternative and new space for the academics to write their narratives, to question and construct their identities, and consider how these constructions changed over time as they engaged socially in their world (Henson et al 2000).

However, as I did not want to force the academics into a predetermined framework, I felt it important that they understood how the email interviews would be conducted (Foster 1994). An interview guide (see Table 1 below) was distributed to explore issues relating to the aims of the research and for context setting. The questions I designed were sent out one at a time and formed a platform from which each academic could start to write their online narratives about how they saw themselves and included:

(i) How have your experiences shaped your professional identity?

(ii) What images would you use to describe your professional identity?

(iii) In what way has your professional identity been shaped by formative experiences?

(iv) In what way is your professional identity shaped across communities of practice?

[insert Table 1 here] 
My approach also placed the interviews within a more naturalistic inquiry in which I discussed the topics and the emergent themes with the participants (see James 2003 for a more detailed methodological discussion). This was further influenced by the pre-existing relationships that existed between the researcher and participants which was already interactive and influential (Lincoln and Guba 1985). This was because I knew all the participants, having already worked with them on a professional basis so I already had access to their email addresses and was able to use them to gain their consent in taking part in the study.

\section{How do Academics See Themselves? Performance and Presentation Online}

Using email as an alternative interview site gave the academics a voice, and a context in which they could begin to explore how they saw themselves. As Giddens (1991) comments, the 'self' in modernity is as a reflexive project that is maintained by the construction of biographical narratives and developed through social interactions and activities that enhance the narrative. As the interviews developed, the academics began to take greater ownership of the processes of narrative construction by responding to my questions in unexpected ways and directions. In return, I responded to the new directions of their narratives by asking further questions about their texts rather than sticking to the original interview schedule (James and Busher 2006)

However, as Gatson and Zweerink (2004) remark, 'the management of presence and presentation' (p.191) is crucial in the conduct of research. In my study, email provided the academics with a more or less open environment to compose their narratives, to recall and better understand how they came to see themselves in their past and present careers as they picked up 
on issues that slipped temporarily out of view through the course of the interviews, and as they returned to earlier aspects of the narrative at their convenience as this participant commented:

‘...this process has made me wonder where it [identity] came from originally...and surprised me how much my identity... as a psychologist/researcher influences the way I conduct my current professional duties...My involvement therefore has been a reflexive one, especially in the times I have been answering your questions and I was able to answer them once I'd given thought to what I wanted to say - there is not much time to reflect otherwise.'

As the academics revisited their narratives, this was unconstrained by time and space to reflect more deeply and learn from their stories of experience (Seymour 2001). Having time to reflect also raised issues about the authenticity of the academics' representations of their experience. As Hardey (2002) notes, biographical narratives can be written and rewritten online. So what is written may not be entirely reflective of the thoughts of the participants (Chen and Hinton 1999). The academics' narratives may have been less authentic as a consequence of spending time reflecting, or the time reflecting may have provided a 'safeguard' as the academics edited the text to convey the meanings they really intended (Mann and Stewart 2000). This raises yet a further issue. Just because the participants did not write something, it does not mean that they were unaware of that point or unable to write about it. This is in keeping with the general process of research interviews, as McCulloch et al (2000) acknowledge: 'All that can be said is that the way the interview played out meant that the point was not spontaneously made at that time in that specific setting. At another time, in another interview, the point might have been made' (p.122). 
Hardey (2002) argues that the Internet creates the potential for individuals to reconstruct their identities. This is because, ...reliance on only textual descriptions provides individuals with the potential to present themselves unhindered by visual images' (p.575). In my study, the academics' online narratives involved varying presentations of self-identity as teacher, researcher, manager, mother and psychologist, as one participant remarked:

'Being interviewed by email made me explore my views and question who I was...to identify issues and put it all into words...it has made me realise that I enjoy being a psychologist and were I able to choose again I would still do the same job...writing my story has given me the opportunity to reflect...in a way that would not happen with the spoken word...

However, this is not just something that occurs online. The construction of identity includes a dimension of complexity and fluidity (Giola and Thomas 1996). It is inextricably linked with who we are, our commitments and values and is 'integral and continuous' (Kendal 1999). As Mann and Stewart (2000) remark, 'For this reason it is seen to be difficult to sustain a persona which is quite divorced from the 'real' self' (p.210). Processes of reflection on identity do not happen in interviews and online exchanges but in everyday life too, as individuals review and rewrite their histories and perspectives in the light of their developing experiences (James and Busher 2006). 
Hardey (2004) has argued that '... disembodiment and anonymity allows users to take on many new identities that may have little connection to their off-line selves' (p.195). Some researchers have addressed this issue by meeting participants off-line whilst others argue that online environments and identities are valid in themselves and do not need to be verified off-line (Hine 2000). Jones (1999) has commented upon how it is the embodied participant who interacts online and that individuals can never escape from lived experiences.

The apparent tension that exists between online and off-line identities raises issues about the nature of 'performance' that can take place online, in terms of how both the participants' and researcher can 'play' with their identity in the social space (Hardey 2004). As Seymour (2001) notes, bodily presence in a face-to-face interview can signify mutuality, commitment and trust through a sense of shared purpose. However, in the online interview this bodily presence is removed. Drawing on Goffman (1969), Hardey (2002) argues that in the 'presentation of self,' text makes invisible the bodily presence as well as outward acts of movement, posture and emotional expression that are important elements in determining how individuals see themselves and how they are perceived by others.

Undertaking my study online meant that I had to deal with how my participants communicated meaning in the social space when non-verbal communication such as gesture, tone of voice and facial expressions were absent (Kendall 2004). Boshier (1990) also notes the possibilities for deception are further exposed because many of the cues that normally circumscribe roles and which foster participation are not present. This may permit the development of '... strategies of visibility of the actors which make up for the lack of traditional interpersonal cues and indeed 
permit the development of a status differentiation...' (Paccagnella 1997). As one of my participants also commented:

Maybe we were sometimes coming from different directions. And maybe in email communication clarification is not always easy. Also sometimes you said "in your email you said" and then I had to think back to what I had said...I found it more demanding in some ways because of this, but it gave me the opportunity to reflect on them [academic identities] sometimes for days... I doubt I would have hand written my responses. Sometimes I wanted to ask 'do you mean this or that exactly' but not being able to do so allowed me to interpret the question in my own term in a way that would not happen with the spoken word...'

Furthermore, the absence of non-verbal cues was offset by the fact the academics' representation of the self 'online' was underpinned by the pre-existing relationships that existed 'off-line' in a professional capacity. In this sense the commonality of identities as academics meant that I did not need to find new ways of building rapport with the academics; as noted by Sade-Beck (2004), '...in these circumstance the virtual world and the 'real world' merge, creating a broader definition of reality.'

This was also aided by the researcher wanting to acquire an '... understanding of the participants' perspective through open and honest dialogue...' (Anderson and Kanuka 2003, p.88). On occasion, the ongoing communication effects between the researcher and participants created a research relationship in which my participants 'performed' as and when it suited them despite my 
text-based cues such as: 'Haven't heard from you in a while. I wondered if you still wished to continue the interview?' This highlighted how during online conversations, the 'lived body' may well be invisible, but the nature of discourses and social interactions can still be influenced by shared meanings and pre-interpretations (Seymour 2001). In recognising the demands that email already placed upon academics, I decided to accommodate the priorities in their professional lives, to give them time to consider the issues, so I waited for them to respond. For the researcher, this created a level of anticipation and reinforced the point that: 'One of the beauties of e-mail is that you never quite know when you will get a response...' (Russell and Bullock 1999, p.134). One participant also remarked:

'I didn't email you straight back, because I was thinking about my answer. So my responses were more carefully thought through and probably longer than if I'd tackled the whole thing in a face-to-face interview... again other ideas would probably not have come out because of the time pressure. This is what's good about the email process because...it allows time to consider the questions and frame an appropriate response.'

Although investing my own identity into the research relationship was an attempt to democratise narrative exchanges, to have a more equal interaction and a dialectical relationship (Illingworth 2001) I consequently took on a different role as a 'participant researcher' (Seymour 2001) as demonstrated by the following email conversation:

P: $\quad$ '....My experiences as an academic psychologist have shaped my professional identity in that I am acutely aware of the rigour with which research is carried out and so 
feel able to lend some authority to observations/judgments based on the robustness of empirical inquiry...'

R: $\quad$ I think that's interesting. In considering the issue myself I have found that my professional identity is linked not only to the working context and the culture within which I work but other identities, which are important to me...These identities merge with each other and are influenced by each other in terms of how I live my life as a whole...'

P: $\quad$ I I absolutely agree with you. For instance, I teach gender and Psychology and regard myself as a feminist, so this has a bearing on how I deliver psychological material and how I am perceived. Similarly I am a parent so when talking about socialisation I feel I can lend some credibility from my own experience. My professional identity is completely bound up with my personality...'

The nature of my role as researcher had involved self-disclosure. I realised that my professional and personal experiences as a 'participant' in online narratives about identity construction were not data that should be omitted, but were in fact the very reasons why I was undertaking the study. Nevertheless, structural power hierarchies also existed which enabled the researcher to set the research agenda, and ask the questions. I wanted to understand how the academics saw themselves and constructed their identities. So in the very first email I sent to the academics, I specifically asked them to reply at the top of the message to ensure that the sequence of their narratives was maintained. This also allowed them to return to earlier parts of the narrative with the aim of getting them to reflect on both the questions and responses before moving to the next 
question. In turn, they presented narratives about themselves that were appropriate for a particular context, and driven by my theoretical concerns (Hardey 2004).

The 'act of identification' (LeBesco 2004) also helped me to further develop rapport with the academics. Again, this was aided by my prior knowledge of the participants on a professional basis. All the participants seemed to want to reflect upon and transmit their experiences faithfully, including aspects of both their professional and personal lives. Perhaps this was because '...the positive effects of the researcher's prior knowledge of the participants led to a more reflexive commentary' (Wicksteed 2000, p.477). In this case the commonality of identities as academics seemed to facilitate genuine narratives, not fictional stories. The participants' lack of inhibition and frankness (Holge-Hazelton 2002) was observed in their more personal narratives which were bound up in dimensions of their lives as they wrote about how their academic identities were socially constructed from interactions with significant others, such as family, friends and teachers. This level of self-exposure reinforced the participants' authentic behaviour (Mann and Stewart 2000) as illustrated in this narrative:

'Interesting to reflect on my professional identity - in many ways I think I deal with the contradictions and sense of being seen as an outsider by not thinking about! Particularly of interest at the moment because I put in for voluntary redundancy... and am wondering how I would cope with not being a psychologist-what would I call myself.... Waiting to hear so in limbo and so anxious in case it doesn't come through, that no space for thinking about identity and coping with its loss.' 


\section{Conclusion: Capturing Academics' Narratives through Email Interviewing}

The paper has explored the possibilities that email interviewing has for studying and understanding academic lives. The study has provided evidence that where research focuses on understanding the creation of academic identities in their voice, email interviewing can at the very least generate narratives that represent their constructed lives, thinking and reflections of their experiences as well as '...give meaning to their lives and capture these meanings in written, narrative...forms' (Denzin and Lincoln 1994, p.10). It invites academics to consider conceptions of how they see themselves as well as new ways of thinking about their identity. As Henson et al (2000) comment: ' ...these stories...give a better understanding of the self-image we construct over e-mail...' (p.180). The freedom offered by virtual communication in terms of time and space aided this process as the academics engaged in critical dialogue about their identities. This in turn provoked some academics to reflect deeper about their professional lives in a way which they might not have done and also helped them to develop a greater understanding of their identity construction.

So whilst email in academics' lives is not always seen as a good thing because of its invasive nature (Reed 2004), it can provide a resource in which academics can write narratives that sustain, enhance or impede events, actions and experiences they regard as important to their identities (Gergen 1994). In this context, email not only served as a 'repository' for the academics' stories, but also allowed for a kind of reflection that significantly informed their thinking about how they saw themselves (Henson et al 2000). It provided an additional space that took into account the way in which the academics' lives continued to take place, and in which 
they could reflect about their experiences in the midst of their experiences at a deeper level (Russell and Bullock 1999). Such space provided '...the potential to bring new meaning to the experiences of change, of growth, and of professional development in a teacher's life' (Beattie 1985, p.8), and provoked new questions about their academic identities.

As the process of interviewing became less preconstructed and instead, more discursive and naturalistic (Seymour 2001), so, perhaps unsurprisingly, the richness of the narratives increased. This seemed to provoke a richness of reflection among the academics beyond what I would have expected had I not allowed the participants to develop their own narratives in ways that were meaningful to them. Indeed as Morgan and Symon (2004) comment: 'This potential increase in reflexivity...may be considered to be a very positive aspect of the medium...because it makes the socially constructed nature of 'reality' more transparent' (p.31).

As discussed in the paper, email interviewing poses challenges for researchers who might wish to use the method as a way of studying and understanding academics' lives, particularly the nature of 'presentation' and 'performance' that takes place with/in email narratives. These academics had benefited in some way from the, '...playful invisibility that text-only space affords' (LeBesco 2004, p.74). The displacement of time which was reinforced by the asynchronous nature of the method, enabled the academics to become engaged in the research process, to consider the issues and explore aspects of their identities and experiences which was lacking in the press of their busy lives, at their own pace until they were ready to deal with them. For them, this was an important part of the process as it provided possibilities for the creation and 
elaboration of online narratives that represented their experiences within a longer-term historical perspective.

Yet, the potential for diffused power relations between researcher and participant online, emphasising the egalitarian nature of email and the genuineness of self-presentation cannot be presumed (Kendal 1999). Essential to this process is the way in which the academics spent time in reflective discourse. This involved the researcher in a non-cohersive exchange where participants could respond when they liked, empowering them to take ownership of their narratives at a time and space convenient to them. However, my role had become such that I had not only become immersed in the online lives of these academics, but my thoughts and reflections had also become part of the ongoing interview process - researcher had also become participant. As Markham (2004) notes: 'This is not a minor point. Our interactions with participants are not simple events in these online spaces, but are constitutive and organizing elements of the space' (p.144). Both participants and researcher responded to responses, through the exchange of narrative, and sometimes connected meaningfully. This is an important element of online ethnography as Markham also reminds us, ‘...methodologically we should not ignore this feature because as interaction constructs and reflects the shape of the phenomena being studied, interaction also delineates the being doing the research in the field' (p.147).

The tension between online and off-line identities and environments in my study reflected broader and well-established debates about authenticity and credibility within qualitative research. Some researchers may argue that to overcome this, the academics could have also been interviewed off-line to assemble a 'complex ethnography' by adding authenticity to their 
descriptions of how they saw themselves, as well as to add depth to my interpretations of their identities (Sade-Beck 2004). After all, although I knew the academics this did not preclude them writing narratives that were sometimes 'superficial and playful' where it was evident that they did always not want, 'to participate in substantive discussion' (Gaiser 1997 p.142). Yet, the very purpose of developing this method, was that the, '... absence of a proper locus [provided] my research participants with a space to explore the aspects of their experiences and identities that otherwise remained initerable' (Eichorn 2001, p.572). In this context, email interviewing created an arena in which the academic self could be articulated and explored, and in which the researcher could study and understand their lives. 


\section{References}

Askling, B. (2001) Higher education and academic staff in a period of policy and system change, Higher Education, 41, 157-81.

Anderson, T. \& Kanuka, H. (2003) e-Research. Methods, Strategies and Issues, (Boston, Ablongman).

Bampton, R. \& Cowton, C.J. (2002) The E-interview, Forum: Qualitative Social Research, 3,(2). Available online at: http://www.qualitative-research.net/fqs/ (accessed 10 September 2004).

Beattie, M. (1995) Constructing professional knowledge in teaching. A narrative of change and development, (New York, Teachers College Press).

Boshier, R (1990) Socio-psychological factors in electronic networking, International Journal of Life-Long Education, 9 (1), 49-64.

Chen, P. \& Hinton, S.M. (1999) Realtime interviewing using the world wide web, Sociological Research Online, 4,(3). Available online at:

http://www.socresonline.org.uk/socresonline/4/3/chen/html (accessed 14 September 2004).

Clandinin D.J. \& Connelly, F.M. (2000) Narrative inquiry: Experience and story in qualitative research, (San Francisco: Jossey-Bass Publishers). 
Clough, P. (2002) Narratives and fictions in educational research, (Buckingham, The Open University Press).

Connelly, F.M. \& Clandinin, D.J. (1988) Teachers as curriculum planners. Narratives of experience, (New York, Teachers' College Press).

Connelly, F.M. and Clandinin, D.J. (1990) Stories of experience and narrative inquiry, Educational Researcher, 19 (5), 2-14.

Connelly, F.M. \& Clandinin, D.J. (1999) Shaping professional identity: Stories of educational practice, (New York, Teachers' College Press).

Cortazzi, M. (1993) Narrative inquiry, (New York, The Falmer Press).

Czarniawska, B. (2004) Narratives in social science research, (London, Sage Publications).

Denzin, N. (2004) Prologue: Online environments and interpretative social research in: M.D. Johns, S.L.S. Chen, \& G.J. Hall (Eds.) Online social research: methods, issues and ethics, (Oxford, Peter Lang Publishing).

Denzin, N. \& Lincoln, Y. (1994) 'Introduction: Entering the field of qualitative research,' in: N Denzin and Y. Lincoln (Eds) Handbook of qualitative research, (London, Sage Publications). 
Eichorn, K. (2001) Sites unseen: ethnographic research in a textual community, Qualitative Studies in Education, 14 (4), 565-578

Foster, G. (1994) Fishing with the net for research data, British Journal of Educational Technology, 25 (2), 91-97.

Gaiser, T. (1997) Conducting on-line focus groups: a methodological discussion, Social Science Computer Review, 15, 135-144.

Gatson, S.N. \& Zweerink, A. (2004) Ethnography online: "Natives" practising and inscribing community, Qualitative Research, 4(2), 179-200.

Gergen, K. (1994) Realities and relationships, (Cambridge, Mass, Harvard University Press).

Giddens, A. (1991) Modernity and self-identity, (Cambridge, Polity Press).

Giola, D.A. \& Thomas, J.B. (1996) Identity, image and issue interpretation. Sense making during strategic change in academia, Administrative Science Quarterly, 41,370-403.

Goffman, E. (1969) The Presentation of Self in Everyday Life, Harmondsworth: Penguin. 
Grant, B. \& Knowles, S. (2000) Flights of imagination: academic women be (coming) writers, International Journal for Academic Development, 5 (1), 6-19.

Halford, S. \& Leonard, P. (1999) New identity? Professionalism, managerialism and the construction of self, in: M. Exworthy \& S. Halford (Eds) Professionals and the new managerialism in the public sector, (Buckingham, The Open University Press).

Hardey, M. (2002) Life beyond the screen: embodiment and identity through the internet, The Sociological Review, 4, 570-584.

Hardey, M. (2004) Digital life stories: Auto/biography in the information age, Auto/Biography, $12,183-200$.

Henkel, M. (2000) Academic identities. Policy change in higher education, (London and Philadelphia, Jessica Kingsley Publishers).

Henson, A., Koivu-Rybicki, V., Madigan, D. \& Muchmore, J.A. (2000) Researching teaching through collaborative inquiry with outside researchers,' in A. Cole \& J.G. Knowles (Eds.) Researching teaching: Exploring teacher development through reflexive inquiry, (Boston, MA: Allwyn and Bacon).

Hine, C. (2000) Virtual Ethnography, (London: Sage Publications) 
Holge-Hazelton, B. (2002) The internet: A new field for qualitative inquiry? Forum: Qualitative Social Research, 3 (2). Available online at: http://www.qualitative-research.net/fqs/ (accessed 14 September 2004)

Illingworth, N (2001) The internet matters: Exploring the use of the Internet as a research tool, Sociological Research Online, 6 (2). Available online at: http://www.socresonline.org.uk/6/2/illingworth.html (accessed 14 September 2004).

James, N. (2003) Teacher professionalism, teacher identity: How do I see myself? Unpublished Doctorate of Education Thesis, University of Leicester, School of Education, July 2003.

James, N. \& Busher, H. (2006) Credibility, authenticity and voice: dilemmas in web-based interviewing, Qualitative Research, 6 (4) (in press).

Johns, S. (2004) Introduction: Ethics and internet studies, in: M.D. Johns, S.L.S. Chen \& G.J. Hall (Eds) Online social research: Methods, issues and ethics, (Oxford, Peter Lang Publishing,)

Jones, S. (1999) Doing internet research, (Thousand Oaks, CA and London, Sage Publications Ltd).

Kendall, L. (1999) Recontextualising cyperspace: Methodological considerations for online research, In S.Jones (Ed) Doing internet research, (Thousand Oaks, CA and London, Sage Publications), 57-75. 
Kendall, L. (2004) Participants and observers in online ethnography, in: M.D. Johns, S.L.S. Chen, \& G.J. Hall (Eds) Online social research: Methods, issues and ethics, (Oxford, Peter Lang Publishing).

LeBesco, K. (2004) Managing visibility, intimacy, and focus in online critical ethnography, in: M.D. Johns, S.L.S. Chen, \& G.J. Hall (Eds) Online social research: Methods, issues and ethics, (Oxford, Peter Lang Publishing).

Leman, P.J. \& Mann, C. (1999) Gender differences in students' performance in examinations: the Cambridge University project, in: P.Fogelberg, J. Hearn, L.Husu \& T. Mankkein (Eds) Hard work in the academy, (Yliopistopaino, Helsinki University Press).

Lincoln, Y.S. \& Guba, E.G. (1985) Naturalistic Inquiry, (Beverley Hills, CA:Sage Publications).

McCulloch, G. Helsby, G. \& Knight, P. (2000) The Politics of professionalism: Teachers and curriculum, (London and New York, Continuum).

Mann, C. \& Stewart, F. (2000) Internet communication and qualitative research. A handbook for researching online, (London, Sage Publication). 
Markham, A.N. (2004) Representation in online ethnography, in: M.D. Johns, S.L.S. Chen, \& G.J. Hall (Eds) Online social research: Methods, issues and ethics, Oxford, Peter Lang Publishing.

Morgan, S.J. \& Symon, G. (2004) Electronic interviews in organizational research, in C. Cassell \& G.Symon (Eds) Essential guide to qualitative methods in organizational research, (London, Sage Publications).

Nixon, J. (1996) 'Professional identity and the restructuring of higher education,' Studies in Higher Education, 21 (1), 5-16.

Nixon, J. Marks, A., Rowland, S. \& Walker, M. (2001) Towards a new academic professionalism, British Journal of Sociology of Education, 22 (2), 227-244.

O’Connor, H. \& Madge, C. (2001) Cyper-parents and cyber-research: Exploring the internet as a medium for research, Sociological Research Online, 5 (4). Available online at: http://www.socresonline.org.uk/5/4/o'connor.html (accessed 14 September 2004).

Paccagnella, L. (1997) Getting the seats of your pants dirty: Strategies for ethnographic research on virtual communities, Journal of Computer-Mediated Communication, 3(1), Available online at: http://www.ascusc.org/jcmc/vol3/issue1/paccagnella.html (accessed 3rd November 2004). 
Polkinghorne, D.E. (1988) Narrative knowing and the human sciences, (Albany, State University of New York Press).

Reed, K. (2004) You've got mail..., AUTLOOK, No 231, p.14.

Russell, T. \& Bullock, S. (1999) Discovering our professional knowledge as teachers: Critical dialogues about learning from experience,' in J. Loughran (Ed.) Researching teaching methodologies and practices for understanding pedagogy, (New York, The Falmer Press).

Sade-Beck, L. (2004) Internet ethnography: Online and offline, International Journal of Qualitative Methods, 3 (2),

Available on line at: http://www.ualberta.ca/ iiqm/backissues/3_2/pdf/sadebeck.pdf (accessed on 3rd May 2005).

Salmon, G. (2000) E-moderating: the key to teaching and learning online, (London, Kogan Page).

Seymour, W.S. (2001) In the flesh or online? Exploring qualitative research methodologies, Qualitative Research, 1(2), 147-168.

Sikes, P. (2002) Series editor's preface in: P. Clough, Narratives and fictions in educational research, (Buckingham, The Open University Press). 
Sproull, L. \& Kiesler, S. (1986) Reducing social context clues: Electronic mail in organization communication, Management Science, 32, 1492-1512.

Weber, S. (1993) The narrative anecdote in teacher education, Journal of Education for Teaching, $19(1), 71-81$.

Wicksteed, A. (2000) Manifestations of chaos and control in the life experiences of individuals with eating disorders: Explorations through qualitative email discourse, Feminism and Psychology, 10 (4), 475-479.

Williams, M. \& Robson, K. (2004) Reengineering focus group methodology for the online environment, in: M.D. Johns, S.L.S. Chen, \& G.J. Hall (Eds) Online social research: Methods, issues and ethics, (Oxford, Peter Lang Publishing,).

Williams, R. (2000) Making identity matter. Identity, society and interaction, (British Sociological Association, Sociology Press). 


\section{Table i. Notes of Guidance for Conducting Email Interviews}

A little while ago you completed a questionnaire, which considered professional identity and how it is managed across communities. You agreed to take part in an email interview, which will address the issues raised in that questionnaire. Please read the following guidelines and if you are still happy to take part in the interview, please reply to this email and I shall send you the first question. The email interviews will consider the issues that arose in the questionnaire in more depth. The data gathered through the email interviews will provide a narrative of your account. These accounts will be used to inform the research study.

In undertaking the email interview please note the following guidelines:

(i) If you are still willing to take part in this study, please reply to this email straight away.

(ii) The interviews will be conducted in strictest confidence and your anonymity will be assured throughout the research project.

(iii) You will be asked eleven substantive questions.

(iv) These questions will be sent to you one at a time. Please respond to the question 
by email. Each question may be followed up by supplementary questions.

(v) It is anticipated that an ongoing dialogue will occur. In order to achieve this, please ensure that you answer on top of the message and question sent to you. PLEASE DO NOT ANSWER AT THE BOTTOM OF IT. This will ensure the sequence of questions and answers is not broken.

(vi) Please do not delete any part of the email dialogue. This will be our record of the conversation.

(vii) Please reply to each email question within three working days if possible. I will also try to reply to your response within that timescale.

(viii) It is anticipated that the email dialogue will be completed within ten weeks.

(ix) Once the dialogue is complete you will given an opportunity to take part in further email discussion 